\title{
Culture of Haalakki Vokkaligas - A Special Reference in Uttar Kannada District
}

\author{
Arati D. Nayak \\ Associate Professor, \\ Department of History, \\ Dr. A.V. Baliga Arts and Science College, Kumata, India
}

\begin{abstract}
Cultural history combines the approaches of anthropology and history to look at popular cultural traditions and cultural interpretations of historical experience. It examines the records and narrative descriptions of past matter, encompassing the continuum of events (occurring in succession and leading from the past to the present and even into the future) pertaining to a culture. As to how they got their name Haalakki is yet to be decided. According to one of their legends - Shiva was ploughing the field. Once, Parvathi tripped and fell down while she was carrying food for Shiva. Rice and milk fell on the mud. She made one male and one female doll out of that mud and returned home. Shiva left ploughing and was coming back searching for Parvathi. He saw the dolls. When he touched them, they came to life. The dolls said, we came to life because you touched us, now what we should do for a living. Shiva said you were born when I was ploughing the field so you continue my work. Therefore, agriculture became the main work for Haalakkis. As they were born out of a mixture of rice and milk, they got the name Haalakki. According to the Mumbai Gazeteer, they got the name Haalakki because they grew rice as white as milk. There are many stories available in the harvest songs suggi haadu and Gumate padas regarding their name and birth. The upper part of Karnataka ghats existed before Konkan belt. Parashurama, who owned the land that came to existence due to sea corrosion, gave this ancient Haiga country to Nagara(Naga) and Muchchi tribes to rule. Later, this was taken by Mogeras and Holeyas.(untouchables)Hence, there were only non-brahmins such as holeyas and bedas living..later Brahmins, Budhdhist and Jains came and settled in this land. There are evidences and folk legends to claim this fact. As Uttara Kannada district is a part of land that was formed as a result of sea corrosion, it supports the fact that Haalakkis came and settled from some other place.In the Suggi songs and Gumte padas of Haalakkis, according to Madevaraya's song, "There was a pariah(holati) woman ruling the seashore lands. This was the reason why the land obtained by Madevaraya was not strong. Hence, Madevaraya killed the pariah woman and obtained a caste each from her flesh/body parts". (Dr.N.R.Nayak, 1989. p.54) Further, according to this song, Madevaraya forgot to create male and female of Haalakki tribe. When they appealed to him regarding their woes, Madevaraya, who was eating milk and rice during that time, made a male and female doll out of it and gave them life. He said there was no need for them to observe 'madi-mailige'(cleanliness rituals) as they were born from milk and rice. According to this legend, all other tribes originate from the pariah woman whereas the origin of Haalakkis is portrayed to be different. However, strong evidence regarding the origins of Haalakkis is yet to be obtained.
\end{abstract}

Keyword: Haalakki vokkaligas, History and Cultural

\section{INTRODUCTION}

Cultural history records and interprets past events involving human beings through the social, cultural, and political milieu of or relating to the arts and manners that a group favors. Jacob Burckhardt (18181897) helped found cultural history as a discipline. Cultural history studies and interprets the record of human societies by denoting the various distinctive ways of living built up by a group of people under consideration. Cultural history involves the aggregate of past cultural activity, such as ceremony, class in practices, and the interaction with locales.

Uttara Kannada district is one of the biggest districts in the state of Karnataka. It is a beautiful place that has been blessed with abundant natural resources. The district has varied geographical features with thick forest, perennial rivers, abundant flora and fauna and a long coastal line of about $140 \mathrm{Kms}$ in length. Uttara Kannada district is bounded by the Belgaum district and the state of Goa in the North, Dharwar District in the East and by Shimoga and Udupi district in the south. The western 
border is formed by the Arabian Sea. Ranking high among the achievements of the state are the Kali Nadi Hydro Electric Project (KPCL) and the NPCL rank among the achievements of the district. Nuclear Power station established at Kaiga by Nuclear Power Corporation Ltd is one of very few in India. It was commissioned on March 5, 2000. This Pressurised Heavy Water Reactor (PHWR) at Kaiga is indigenously designed, meets the latest safety standards and has state-of-the-art technology including computerized controls.

History of Uttara Kannada District the Kadamba rulers ruled over Uttara Kannada district, particularly the region of Banavasi. This area was reigned over by the kings of Vijayanagar empire, Hoysalas, Chalukyas, Rashtrakutas after the Kadambas were defeated. Remnants of a ruined mosque can be noticed in Honnavar town. The Marathas controlled this region during the 1750's, and later it was annexed by the Mysore kingdom. However, after the Fourth Mysore War in 1799, it was occupied by the British. In 1859, Uttara Kannada district was divided into South Kinara and North Kinara districts and in 1862 the district passed into the Bombay Presidency. In the year 1956, the southern part of Bombay state was included within Mysore, which was later renamed as Karnataka in 1972. This district was an important trade centre since it was visited by Portuguese, French, Arabs, Dutch and British. The famous traveller Ibn Batuta had passed through this place during one of his travels. Rabindranath Tagore, the Bengali poet and nobel laureate had paid a visit to this district during 1882, along with his brother Satyendranath Tagore, when he was 22 years old. Uttara Kannada district has been referred to in the Treaty of Mangalore which had been signed in the year 1784 between the East India Company and Tipu Sultan.

Culture of Uttara Kannada District there is a quite a substantial tribal population found settled in the district. The main tribes of the district are Sidhi, Kunabi, Haalakki Vokkaliga, Gonda and Gouli. As regards the culture and festivities typical to the place, folk arts like Suggikunitha, Holi Dance, Hulivesha, Siddi Dance are famous and traditional. Yakshagana is also famous in the district. The major regional languages spoken by the people of the Uttara Kannada district are Kannada language and Konkani language. The regional cuisine of Uttara Kannada district consists of delectable seafood and the staple diet of the local inhabitants of this region is rice. Coconuts and cashew nuts are also relished by the people of this district. Tea is also enjoyed by them and it is often flavoured with mint or cardamom. Diwali, Eid Ul Fitr and Eid-Ul-Adha are the other festivals celebrated here.

If we follow the rough, narrow by lanes of National Highway 17 of Uttara Kannada district, the rough road never seems to end. Amongst the furrows beside the road where areca nut, coconut trees and plantains grow, we can spot earthen houses with thatched roof. The front yards are daubed clean with cow dung, a sacred house for Tulasi, a 'jagali' to sit down while having the ritual betel leaves and arecanuts, a fine chicken coop made of packed earth on arecanut poles.

An old man pounding betel leaves and arecanuts, the woman peeping from the cowshed with lots of black, yellow and blue beaded necklaces, when you go near them and speak an emanating feeling of warmth only felt in the family, their natural hospitality - asking their guests to sit on a mattress. These are the Haalakki people.

Although only a few kilometers away from the National Highway, the Haalakki people have remained unique, aloof from the civilized world.

\section{Area of the Study on Culture of HaAlakki Vokkaligas}

\subsection{Name and Origin of Haalakki Vokkaligas}

There are no concrete evidences regarding the origins of Haalakki Vokkaligas. However, Dr. R.N. Nayak, who has worked extensively regarding the folk culture of Uttara Kannada gives the following reasons as to why it can be assumed they originate from Andhra:

1.They are the staunch followers of Thirupathi Thimmappa.

2. Their songs often mention eastern sea.

3. Telugu word 'haalika' is very much similar to Haalakki.

The pronunciation differences in their language such as Na-na, La-la, sa-cha are similar to that inTelugu.The language of Halakki people is Achchagannada. They are the devotees of Thirupathi Thimmappa. Every house compulsorily has a Tulasimane. It is a curious fact as to how these Haalakkis, inhabitants of west coast became devotees of eastern Thirupathi Thimmappa. Hi Chi Boralingaiah suggests that the Haalakki Vokkaligas, Gondas, Gamokkalus and Kare Vokkaligas who 
earlier used to worship gods such as Byate Beera, Masthi and Chowdi must have come under the influence of Vaishanavism during a special time period.

When their traditional rituals and devotional practices are observed, matriarchal culture stands out. Forest plants, animals, hills and brooks are symbols of their clans, which suggests a matriarchal society and that they originated from the forests. Now, they have forgotten the names of their ancient clans

Folk scholar Dr. N.R. Nayak says that this group entered Uttara Kannada from Goa's direction, stayed in Baithkola of Karavara in the beginning. Haalakki people recognize a hill of this region as their tribe's village.

\subsection{Native}

Haalakki Vokkaligas can be seen on both sides of National Highway 17 that passes through Karwar, Ankola, Kumata, Gokarna and Honnavar tallukas of Uttara Kannada district and the parts of land touching the waters of Arabian sea. There are many remnants of ancient society indicating that there was independent, self-rule. The underlying system of their society is very different. The whole population of the Haalakki tribe has been divided into 7 regions. The religious rituals are bound by these regions. The seven regions are Chandaavara, Gokarna, Kadavaada, Ankola, Nushi Kote, Kumbaara Gadde and Haritte Seemey. A group of Haalakki huts is called 'Koppa'. Many Koppas together form a seemey. Each Koppa has a Gowda and a Budavantha and a Kolkaara to assist him. Leader of the Seemey is called Arasu or Gowda. The power is hereditary. If the judgement pronounced by the Gowda of Koppa is contested, leader of Seemey makes the judgement.

\subsection{Haalakki Woman}

Haalakki women have maintained their own culture, although in contact with the main civilization. They continue to astonish cultural thinkers amidst all the modernity.Their backs are dark coloured, always exposed to the sun, their shiny black hair is well oiled and combed, 'abbalige' or 'muthumallige' flowers adorn their heads, black beaded necklaces are worn from neck to shoulder, a german silver 'Halkadi' or 'bandhi' made of thick metal plating, 4-5 worn out brass shoulderbands shiny and golden, glass bangles in the left hand and bangles made of german silver or some cheap metal on the right hand, (It is unknown as to why they believe glass bangles should not be worn on the hand that gives food to their husband.), saree worn in a special way without a blouse.. all these are the specialties of Haalakki women.

\subsection{Regional Differences in the Same Tribe}

Careful observation shows a marked difference in behaviour, dressing, jewellery, way of looking at life, personality and many other things among Halakki women from one place to the other. Haalakki women of Ankola are jovial talkers. They can happily spill out hundreds of songs in an effortless manner. Only the Haalakki women of Ankola can sing and dance "Thaarley Thaarley.." a rain dance.Haalakki women of Honnavara are soft natured. They speak only when it is required. Their songs have a soft quality and are sung in a low-pitched voice. Surprisingly they do not know to dance 'Thaarley'. Haalakki women of Ankola wear short black beaded necklaces around their neck.Haalkki women of Honnavara wear long yellow, and black beaded necklaces. They wear glass bangles only on the left hand. The kind of brass shoulder bands worn by these women are not seen among the Haalakki women of Ankola.

Haalakki women of Ankola wear their sarees short, like a skirt unlike the Haalkki women of Honnavara who wear their sarees long. It looks beautiful when the folds tucked to side of their waists, and they sway while they carry their bundles of firewood on their heads. The reasons for such difference among Haalakki women of Ankola and Honnavara are yet to be found. Their harvest dances too exhibit a lot of regional difference. There are notable differences in the harvest dancing style, costume, songs, singing, and literature etc. from region to region. Probably, these races found it difficult to communicate after migrating to different regions because of hills, mountains, rivers and forests. Tribal castes could not mingle with each other since status-based caste resrictions were tighter in the olden days. Hence these differences in behaviour, clothing etc. remained intact. Haalakkis of Honnavara interacted with soft natured Havyaka Brahmin women. At the same time, Haalakki women of Ankola interacted with Naadavaru who were Kshathriyas. This too might have influenced their personalities and behaviour. 


\subsection{Tribal Ramayana and Mahabharatha-Pandavarakami-Seethekami}

When Haalakki women sing the stories of Ramayana and Mahabharatha, a new world opens up. They call Mahabharatha as Pandavara kami and Ramayana as Seethekami. According to their songs, it was not Rama but Lakshmana who won Seetha!! Lakshmana did not break any bough to win Seetha. Instead, he kills a crow (kaa mandala kaage) that hindered king Janaka's meditation. These songs of tribal Ramayana contain wonderful imagery like that of a cobweb in the throat of Lakshmana who does not touch food or water for his elder brother. In Seethe kami, Seetha's personality is more important than Rama. This is much longer than Pandavara Kami and has to be sung the whole night. But people who can sing Kamis elaborately are not available. Sometimes i feel Ramayana and Mahabharatha were born amongst such people. The stories are so original and you began to think when Rama becomes godly figure.

Sukri,Nugli, Padmavathi who are associated with buDa folklore since many years as resource persons. They can sing for days and nights together. These women are not just singers, they know many herbal medicines.If you go for a walk with Sukrajji there is a story to tell for each and every plant you meet on the way .Each plant will be identified. Padmavathi is a very spontaneous singer and narrates the stories so well.

\subsection{Work}

In the beginning, Haalakki Vokkaligas stayed like Thodas of Nilagiri near the foothills and depended on Kumbri system of agriculture. When British government banned Kumbri agriculture, they gradually migrated to riverbanks, seashores, flatlands and started working for landlords. Many of them, even today, work on Geni basis. Some own pieces of land after 'tiller is the owner' legislation was passed. After hunting was declared illegal, they are dependent upon agriculture for their livelihood.

They have a middle position between forest and the city. Their symbolic hunt once a year and their prayer-appeal to Byate Beera suggest their strong ancient connection with the forest and their cheerful harvesting festival suggests that they gradually turned to agriculture.

\subsection{Halakki Harvest Dancing:}

\subsubsection{Suggi Dance}

Some 50 years ago, during the full moon annual harvesting, whole village used to participate in preparing the harvest gear called Suggithurayi and Kunchas. The whole village used to enjoy during the festival as a community. Even the village head Gowda used to touch the feet of Suggi Makkalu the harvest dancers. The whole harvest dancing team - Suggi mela - used to consider themselves as one family. A remnant of tribal life can be seen here.

\subsubsection{Singing gumte pada at salikeri}

There is a need focus on this and study the idea of a strong social system behind tribal rituals in depth.Haalakkis, who were originally hunters, used the skin of monitor lizard for their unique drum 'Gumte', an instrument used during harvesting festival dance. As hunting is illegal now, many new instruments have come to existence.

\subsubsection{Gumte-the earthen musical instrument of Halakki tribe}

The lack of peacock feathers used in Kunchas, bendu - a thing used in thurayis, and monitor lizard skin for drums has played an important part in bringing about a change in the costumes of Suggi Kunitha - harvest dancing.

\section{REFERENCES}

[1] Siegfried Giedion, Space, Time and Architecture (6th ed.), p 3

[2] Arcangeli, Alessandro. (2011) Cultural History: A Concise Introduction (Routledge, 2011)

[3] Burke, Peter. (2004). What is Cultural History?. Cambridge: Polity Press.

[4] Cook, James W., et al. The Cultural Turn in U. S. History: Past, Present, and Future (2009) excerpt; 14 topical essays by scholars

[5] Ginzburg, Carlo (1989). Clues, Myths and the Historical Method. Johns Hopkins University Press. 
[6] Hérubel, Jean-Pierre V.M. (2010, January). "Observations on an Emergent Specialization: Contemporary French Cultural History. Significance for Scholarship." Journal of Scholarly Publishing 41\#2 pp. 216-240.

[7] Kelly, Michael. "Le regard de l'étranger: What French cultural studies brings to French cultural history." French Cultural Studies (2014) 25\#3-4 pp: 253-261.

[8] Kırl1, Cengiz. "From Economic History to Cultural History in Ottoman Studies." International Journal of Middle East Studies (2014) 46\#2 pp: 376-378.

[9] McCaffery, Peter Gabriel, and Ben Marsden, eds. The Cultural History Reader (Routledge, 2014)

[10] Melching, W., \& Velema, W. (1994). Main trends in cultural history: ten essays. Amsterdam: Rodopi.

[11] Morris, I. (1999). Archaeology as Cultural History: Words and Things in Iron Age Greece. Blackwell Publishing.

[12] Munslow, Alun (1997). Deconstructing History. Routledge. Poirrier, Philippe (2004), Les Enjeux de l'histoire culturelle, Seuil.

[13] Dr. Savita Uday . culture of haalaki vokalligas 